\title{
Contribution to the development of product category rules for ceramic bricks
}

\author{
Marisa Isabel Almeida ${ }^{a, *}$, Ana Cláudia Dias ${ }^{\text {b }}$, Martha Demertzi ${ }^{\text {, }}$, Luís Arroja ${ }^{\text {b }}$ \\ a Department of Environment and Planning, University of Aveiro \& Technological Centre for Ceramic and Glass Industry, Rua Coronel Veiga Simão, \\ 3025-307 Coimbra, Portugal \\ ${ }^{\mathrm{b}}$ CESAM - Centre for Environmental and Marine Studies \& Department of Environment and Planning, University of Aveiro, \\ Campus Universitário de Santiago, 3810-193 Aveiro, Portugal
}

\section{A R T I C L E I N F O}

\section{Article history:}

Received 11 November 2012

Received in revised form

27 July 2014

Accepted 21 December 2014

Available online 27 December 2014

\section{Keywords:}

Ceramic brick

Building product

Environmental Product Declaration (EPD)

Life cycle assessment (LCA)

Product Category Rules (PCR)

\begin{abstract}
A B S T R A C T
An Environmental Product Declaration (EPD) provides information on a product's environmental performance along its life cycle. This paper aims to contribute to the development of Product Category Rules (PCR) specific for ceramic bricks in order to support the establishment of a "cradle to grave" EPD. The methodology for developing the PCR takes into account ISO 14025, ISO 21930 and EN 15804, and the environmental profile is based on the Life Cycle Assessment (LCA) methodology. In this context, some core issues like product category definition, impact categories, indicators, cut-off criteria and allocation criteria are addressed. The selected impact categories for this study were: global warming, ozone layer depletion, photochemical oxidation, acidification, eutrophication, depletion of abiotic resources and respiratory inorganics. Indicators of energy and water consumption were also considered, as well as particle emissions to air. The results obtained from an LCA study on ceramic bricks produced in Portugal, to support the development of the PCR, show that the use of different fuels in the brick manufacturing stage has a significant effect in some impact categories. The use of petroleum coke generates higher impacts than natural gas or biomass. In general, the major environmental impacts occur in the brick manufacturing stage, mainly due to fuel usage in the firing operation. Particle emissions to air should be considered as an additional parameter in the EPD, being especially important when solid fuels are used. A sensitivity analysis of the cut-off criteria options was also conducted, which concluded that a $0.5 \%$ decrease in mass proved to be adequate for adoption, with a significant reduction in the effort required for data collection.
\end{abstract}

() 2014 Elsevier Ltd. All rights reserved.

\section{Introduction}

Several European and international instruments and policies (e.g. EC (2001), EC (2011a, 2011b), ISO (1999a, 1999b, 2006a, 2006b, 2008)) have been pointing out the importance of Environmental Product Declarations (EPDs) as relevant communication tools for the environmental aspects and impacts associated with products throughout their life cycle, and that they can also act as tools for the improvement of sustainability. EPDs (type III environmental declarations according to ISO 14025 (ISO, 2006b)) provide quantified environmental data for a product using predetermined parameters based on life cycle assessment (LCA) in accordance with the ISO

\footnotetext{
* Corresponding author. Tel.: +351 239499 200; fax: +351 239499204.

E-mail address: marisa@ctcv.pt (M.I. Almeida).
}

14040 series of standards (ISO, 2006c, d). They are designed to communicate verifiable and accurate information to different stakeholders regarding the environmental aspects and impacts of products and services. They also encourage the improvement of the environmental performance, and provide information for assessing the environmental impacts over the life cycle of products. The use of EPDs can stimulate competition between material manufacturers and therefore promote more eco-efficient products (Ingwersen and Stevenson, 2011). EPDs are also an important tool for market communication and a basis for eco-design, although the amount of work and competence required to perform a full EPD based on LCA has been identified as a major obstacle for small and medium sized enterprises (SMEs) (Zackrisson et al., 2008).

EPDs must be conducted under specific agreed guidelines for each product category, known as Product Category Rules (PCRs). The PCRs include, among others, the description of the product 
category, the functional unit (or declared unit), system boundaries, cut-off criteria, allocation rules, information on the use phase, units, calculation procedures, requirements for data quality and parameters to declare in the EDP, materials and chemicals, and other relevant environmental information. From the perspective of buyers and end consumers, the EPDs for products fulfilling the same function need to be comparable, so efforts need to be done in aligning existing PCRs and developing new PCRs that can permit consistent comparison of products (Hunsager et al., 2014; Ingwersen and Stevenson, 2011; Subramanian et al., 2012).

Therefore PCR should be very specific in terms of content, both in general requirements (e.g. product category definition, reporting format), and also in LCA methodology (e.g. system boundaries, inventory analysis, allocation rules, indicators, methods) (Ingwersen and Subramanian, 2013; Subramanian et al., 2012). Rules for the use of specific and generic data, and foreground and background processes should also be specified (Modahl et al., 2013).

The construction sector has played a very active role in the development and harmonization of EPDs. This sector consumes more raw materials than any other industrial sector and it also involves high energy consumption (Koroneos and Dompros, 2007; Misiga, 2012; Ronning and Lyng, 2011). In Europe, the building sector consumes $40 \%$ of the total energy and raw materials, emits $36 \%$ of the total greenhouse gas (GHG) emissions and produces $15 \%$ of the total industrial waste (Misiga, 2012). Among the most commonly used construction materials, Brilián et al. (2011) have highlighted that steel, cement and ceramic materials are the most energy intensive construction materials. Ceramic products are one of the oldest building materials and generate a series of environmental impacts over their life cycle (Almeida et al., 2011; Bovea et al., 2007; Bribián et al., 2011; Center for Clean Products, 2009; Ibáñez-Forés et al., 2013; Koroneos and Dompros, 2007; Rouwette, 2010).

With the publishing of European standard EN 15804:2012, "Sustainability of construction works - Environmental product declarations - Core rules for the product category of construction products" (CEN, 2012), the existing European EPD programmes have had to adjust their core PCRs for construction products to be consistent with this standard. Despite the fact that the EN 15804 standard provides core PCRs, specific rules for subcategories of construction products will still be necessary and efforts to harmonize them at an international level have to be made in order to guarantee their comparability. The ECO Platform was created for EPD Programme Operators in Europe to agree on common rules based on EN 15804 principles and procedures (PCR harmonization), which will lead to mutual recognition of EPDs (Eco-platform, 2014).

There are more than 30 EPDs in Europe for ceramic bricks, but they differ in several aspects such as the type of brick, function, usage of ancillary materials and additives, environmental impact categories, sources of data, system boundaries and EPD format. Although there are some EPDs for bricks, no PCR for this product category could be found, which compromises the comparability of the existing EPDs.

Some LCA studies have also been conducted on a number of ceramic brick products (Almeida et al., 2011; Bribián et al., 2011; Koroneos and Dompros, 2007; Rouwette, 2010), but comparison is difficult because they have different system boundaries, sources of data, impact indicators and impact assessment methodologies, and none of these studies have evaluated the effect of using different rules in the LCA calculation, such as cut-off criteria or allocation procedures.

This study aims to contribute to the development of a specific PCR, that allows for a comparison of the environmental performance of ceramic bricks, establishing some rules that can support a coherent PCR, namely through a sensitivity analysis in order to evaluate the effect of using different cut-off criteria and allocation rules. For this purpose, a "cradle to grave" LCA of ceramic bricks produced in Portugal is considered as well as previous LCA studies of ceramic materials. On the other hand, the use of different fuel sources (natural gas, biomass and petroleum coke) for the firing unit operations and a comparison of the derived environmental impacts based on the LCA have never been performed. This LCA study also intends to establish reference values for the environmental burdens when different fuels are used in the brick production factory.

\section{Methodology}

The methodology used in this study followed the ISO 14025 (ISO, 2006b), ISO 21930 (ISO, 2007) and EN 15804 (CEN, 2012) specifications for the development of the PCR to support the development of the EPD for ceramic bricks.

Previous LCA studies on ceramic materials (Almeida et al., 2011; Bovea et al., 2007; Bribián et al., 2011; Center for Clean Products, 2009; Ibáñez-Forés et al., 2013; Koroneos and Dompros, 2007; Rouwette, 2010) were also considered as background information for the development of specific PCR to ceramic bricks, namely relevant indicators and impact categories for this construction material.

Fig. 1 schematically presents the methodology followed in this work. This methodology began with the product category definition, followed by the development of the PCR, which defines the criteria, requirements and guidelines for the specific product category and defines the parameters for preparing and developing the EDP. The LCA methodology was applied to quantify the environmental impacts associated with the brick life cycle from a "cradle to grave" perspective, taking into account the ISO 14040 and ISO 14044 standards (ISO, 2006c, d). This study also includes a sensitivity analysis in order to evaluate the effect of using different cut-off criteria and allocation rules on the magnitude of the impacts.

\subsection{Definition of the product category}

The product category is ceramic bricks according to NP EN 771part 1 (CEN, 2011), consisting of clay masonry units made from clay or other argillaceous materials fired at a sufficiently high temperature to achieve a ceramic bond. These bricks have a gross dry density less than or equal to $1000 \mathrm{~kg} / \mathrm{m}^{3}$.

These bricks are characterized by different sizes, void percentages and material densities.

\subsection{Development of the LCA study}

For the development of an LCA study to quantify the environmental impacts of an EPD, it is necessary to follow precise methodological rules as defined in PCRs in order to guarantee the comparability of different EPDs to products with the same function.

Since brick factories use different fuel sources, three scenarios were developed considering the fuel type used in the brick production phase:

- Scenario NG - Natural gas (average data from three representative factories):

- Scenario BIO - Biomass (average data from three representative factories) using woodchips, pine bark, sawdust and cork dust;

- Scenario PC - Petroleum coke (average data from two representative factories). 


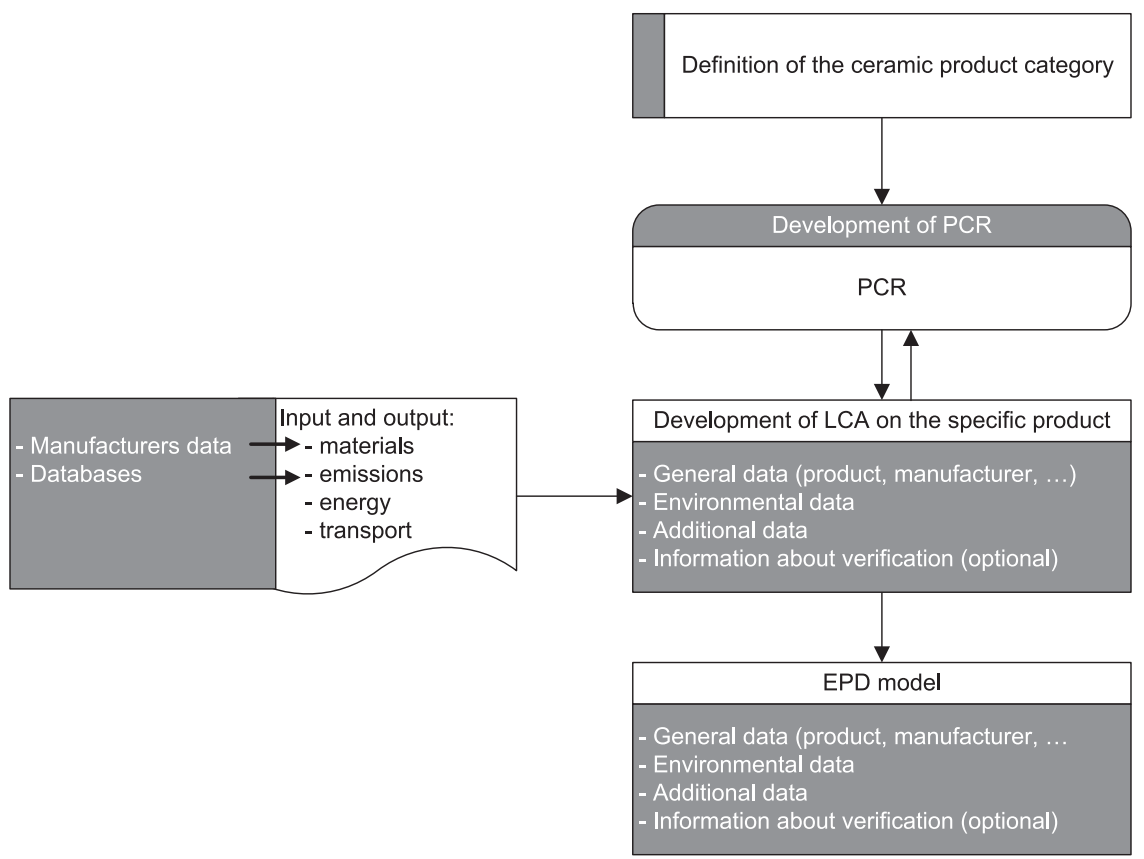

Fig. 1. Methodology for developing an EPD for ceramic brick.

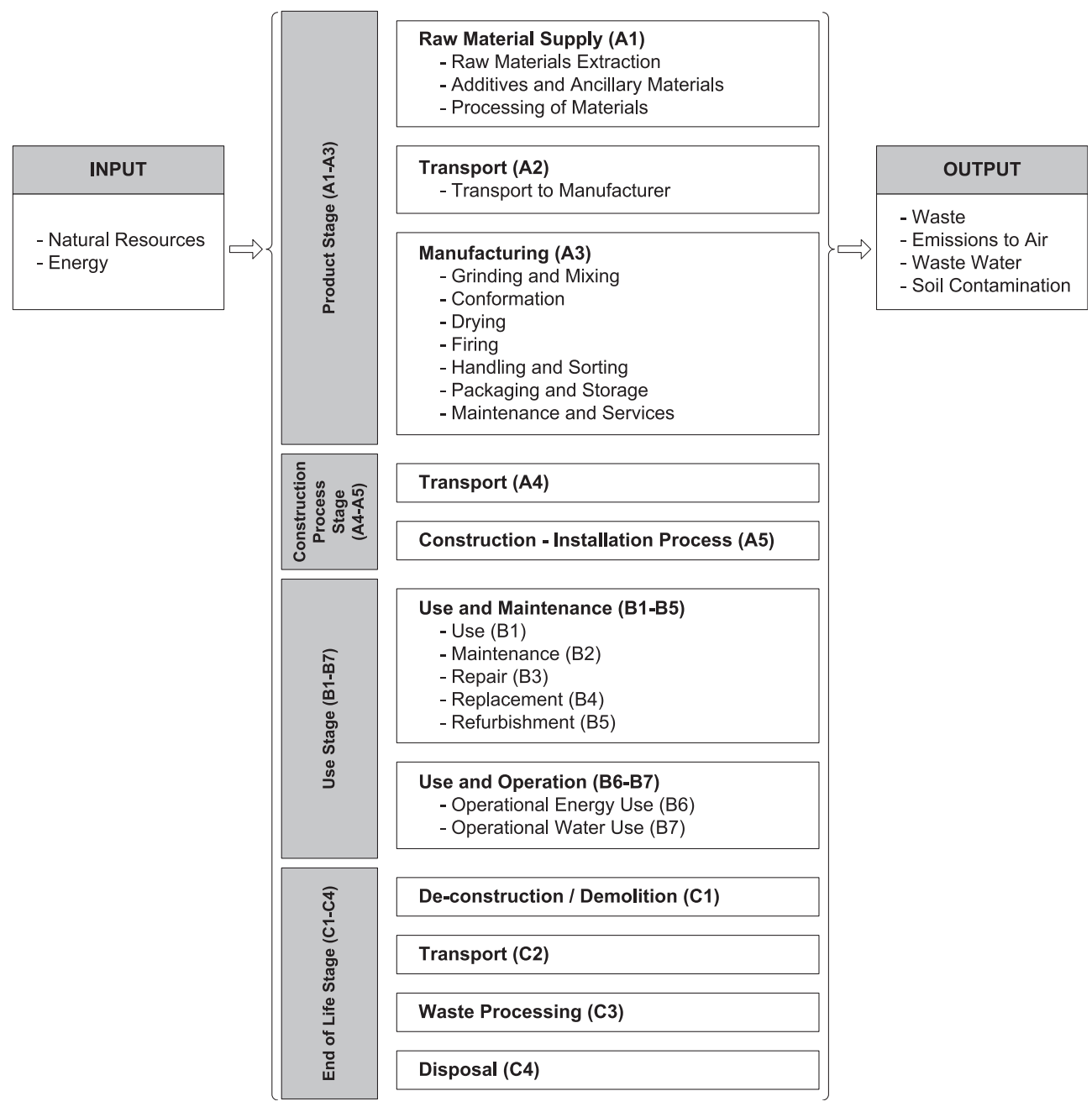

Fig. 2. The life cycle stages and system boundaries for the ceramic brick according to EN 15804 . 
It should be mentioned that in all factories under study the typology of raw and ancillary materials as well as the technologies used in the production process is similar.

\subsubsection{Goal definition}

The aim of this study was to identify and assess the environmental impacts associated with the ceramic brick life cycle from "cradle to grave" using an LCA approach to quantify the environmental impacts of the ceramic brick.

It also intends to establish specific PCR rules and reference values for the environmental burdens when different fuels are used in the brick production factory.

\subsubsection{Functional unit}

The functional unit constitutes the reference flow to which all other flows in the LCA study are related. The functional unit used was $1 \mathrm{~m}^{2}$ of a single layer brick wall without a finishing cover layer (with brick dimensions of $30 \times 20 \times 11 \mathrm{~cm}$ and a total equivalent weight of $71.6 \mathrm{~kg}$ ) for a period of 50 years (typical building life time). However, results are also presented in relation to the declared unit of $1 \mathrm{~kg}$ of brick ready to be sold for a period of 50 years.

\subsubsection{System boundary and description}

The system boundary includes all processes from "cradle to grave", which include the extraction and acquisition of raw materials, ancillaries and additives and their transportation to the production sites, the brick production process, the distribution of the brick, the brick installation in the building site, wall use and the wall end of life.

The construction and maintenance stages of the factories and remaining infrastructure, the production of manufacturing equipment and personal activities (such as the transportation of employees) were excluded from the boundaries of the study.

Fig. 2 presents the system boundaries for the ceramic brick, identifying the different stages and processes associated with the "cradle to grave" assessment according to the scheme presented in EN 15804.

\section{a) Product stage (modules $\mathrm{A} 1-\mathrm{A} 3$ )}

The brick is mainly composed of clay (more than 90\%), some sand and internal by-products. Although clay is an abundant mineral in Portugal, the clay used for the production of bricks must have specific properties (e.g. plasticity) that allow it to be properly shaped and moulded. The raw materials usually come from quarries (module A1) in the vicinity of the ceramic factory $(<50 \mathrm{~km})$. All the raw materials are transported in bulk by truck (module A2).

The brick manufacturing process (module A3) includes the following unit operations: storage of raw materials; raw material preparation; conformation by extrusion; drying; firing; sorting; packaging; and storage.

The raw materials, composed of several kinds of clay and sand, are mixed and kneaded to attain a homogenisation of the mass and therefore obtain a good plasticity. The prepared mass is aged and soured through storage for further homogenisation. Water may be added. The mixed clay is submitted to a shaping method such as extrusion to form the desired product shape. The humidity of extrusion is about $18-20 \%$ in weight $(\mathrm{w} / \mathrm{w})$.

After extrusion, the brick enters the drying process using tunnel dryers for between less than eight and $72 \mathrm{~h}$ at a temperature of approx. $75-90^{\circ} \mathrm{C}$. Dryers are heated mainly by excess heat from the kiln and, in some cases, complemented by natural gas or other fuel burners, mainly during the winter season. The water content in the dried brick is usually lower than $3 \%$.
After the drying process, the bricks are ready to be submitted to the firing operation. The most common technology used in this operation is tunnel kilns operating at an oxidising atmosphere (typically $18 \%$ oxygen). Green bricks are placed directly on the tunnel kiln car. The ware to be fired passes through the kiln on a series of kiln cars and is heated up to a temperature of $800-1000{ }^{\circ} \mathrm{C}$. Following the necessary body formation time of between two and $5 \mathrm{~h}$ at maximum temperature, the brick is cooled down according to plan to $50{ }^{\circ} \mathrm{C}$. The total firing time is about 17-25 h.

Bricks are sorted automatically or manually during the unloading of the tunnel kiln car, then packed (with plastic) and palletised for transportation to a shipping unit.

Besides brick manufacturing, this stage also includes materials, energy and emissions from the production of raw, ancillary materials and packaging materials (plastic and wood pallets), and electricity and fuel consumed in the production of the ceramic brick.

\section{b) Construction stage (modules A4-A5)}

This stage includes brick transportation and brick installation in the building, as well as the production of mortar, energy and water required for the construction of the brick wall.

It also includes the materials, energy and emissions for the transportation of bricks by truck as well as the production of diesel (used by the truck).

For the transportation of the brick to the building site, a scenario of $100 \mathrm{~km}$ was assumed. The bricks are transported in trucks weighing 25 tonnes.

The placement of the bricks is done manually with $1 \mathrm{~cm}$ cement mortar seals. Typical compositions of mortar for brick laying are cement, sand and water.

For $1 \mathrm{~m}^{2}$ of brick wall (type $30 \times 20 \times 11$ ) with $1 \mathrm{~cm}$ seals, typical values of $29 \mathrm{~kg}$ of mortar and $13-14 \%$ of water were assumed. The external layer of the wall was not considered.

During the construction of the brick wall, the produced waste material from breaking or cutting the bricks for the wall (brick losses of 3\%), the packaging waste and environmental aspects linked to the transportation to waste processing and disposal facilities were considered.

\section{c) Use stage (modules B1-B7)}

The brick does not require any material or energy consumption after installation and does not release any emissions to the environment.

Therefore, in this specific study, the use stage (modules B1-B7) is not relevant in terms of mass, energy or other environmental aspects (inputs or outputs).

\section{d) End of life stage (modules C1-C4)}

This stage includes the deconstruction of the brick wall and the treatment of this demolition material. Currently, the final disposal process for ceramic bricks in Portugal consists of its use as filler material in infrastructure (e.g. the foundations of buildings) after crushing or landfill disposal. This stage includes landfill emissions, the transportation of the brick waste by truck to the landfill site (an average distance of $50 \mathrm{~km}$ was assumed) and the production of the diesel used by the truck.

\subsubsection{Cut-off criteria}

The purpose of using cut-off criteria is to decide which processes can be excluded from the system boundaries without significant changes in the LCA results. 
Table 1

Data sources used in the inventory.

\begin{tabular}{|c|c|c|c|}
\hline Element & Module & Data description & Data source \\
\hline Extraction of raw materials & A1 & Inputs and outputs & Portuguese extraction industry \\
\hline $\begin{array}{l}\text { Processing of ancillary } \\
\text { materials }\end{array}$ & A1 & Inputs and outputs & Ecoinvent database (Ecoinvent, 2009) \\
\hline $\begin{array}{l}\text { Transport of materials to } \\
\text { the brick manufacturing } \\
\text { plant }\end{array}$ & A2 & $\begin{array}{l}\text { Distance, transport mode, type } \\
\text { of fuel }\end{array}$ & $\begin{array}{l}\text { Extraction industry and brick production factories for quantities, distance, } \\
\text { transport mode and type of fuel. } \\
\text { Ecoinvent database for emission factors }\end{array}$ \\
\hline Brick manufacturing plant & A3 & Inputs and outputs & Brick factories, representative of the national production and technologies. \\
\hline $\begin{array}{l}\text { Transport to the building } \\
\text { site }\end{array}$ & A4 & $\begin{array}{l}\text { Distance, transport mode, type } \\
\text { of fuel }\end{array}$ & Ecoinvent database (Ecoinvent, 2009) \\
\hline Mortar production & A5 & Inputs and outputs & $\begin{array}{l}\text { Ecoinvent database (Ecoinvent, 2009) } \\
\text { Mortar composition based on Secil (Secil, 2005) }\end{array}$ \\
\hline $\begin{array}{l}\text { Installation in the building } \\
\text { (brick wall with cement } \\
\text { mortar) }\end{array}$ & A5 & Inputs and outputs & Construction industry \\
\hline $\begin{array}{l}\text { Electricity production } \\
\text { (Portuguese mix) }\end{array}$ & A1, A3, A5 & Inputs and outputs & Ecoinvent database (Ecoinvent, 2009) \\
\hline Diesel production & A1 to $\mathrm{A} 4 . \mathrm{C} 1-\mathrm{C} 4$. & Inputs and outputs & Ecoinvent database (Ecoinvent, 2009) \\
\hline Use stage & B1-B5 & $\begin{array}{l}\text { No consumption of energy and } \\
\text { materials }\end{array}$ & - \\
\hline End of life (deconstruction) & $\mathrm{C} 1$ & $\begin{array}{l}\text { Diesel consumption in the } \\
\text { demolition machines }\end{array}$ & Ecoinvent database (Ecoinvent, 2009) \\
\hline $\begin{array}{l}\text { End of life (waste } \\
\text { management and } \\
\text { disposal) }\end{array}$ & $\mathrm{C} 3-\mathrm{C} 4$ & Waste scenario & Construction industry and ecoinvent database (Ecoinvent, 2009) \\
\hline
\end{tabular}

By default, all the processes occurring from "cradle to grave" were accounted for and therefore no cut-off criteria were established. In order to provide information for the establishment of the PCR for ceramic bricks, a sensitivity analysis was carried out consisting of analysis of the effects of using several cut-off criteria options:

- Option I - No cut-off criteria;

- Option II - To exclude $1 \%$ of renewable and non-renewable primary energy usage and $1 \%$ of the total mass input of each unit process according to EN 15804;

- Option III - To exclude the inputs and outputs that represent less than $0.5 \%$ of the mass of the ceramic brick ready to be sold;

- Option IV - To exclude the inputs and outputs that represent less than $1 \%$ of the mass of the ceramic brick ready to be sold.

It should be noted that in all these options the hazardous substances were always included, regardless of the cut-off criteria used.

The natural gas scenario was chosen as a case study for the sensitivity analysis as it is the BAT for the ceramic sector and is a relevant fuel in Portugal.

\subsubsection{Inventory analysis}

The inventory data include inputs (raw and ancillary materials, fuels, electricity and water) and outputs (products, emissions to air, water and soil) for each process included in the system boundaries (A1-C4), as shown in Table 1.

Primary data (direct measurements made along the supply chain from processes owned, operated or controlled by the organization under study) concerning brick manufacturing was collected at brick mills and quarries. Data for the raw material extraction was collected directly from the quarries that supply the industry and refer to the year 2008 (January to December). This year is representative of the typical brick production, as it was not affected by the economic crisis in the sector. The technologies and fuels used are still representative of those currently in use.
The transportation distances and types of transport between raw material extraction sites and brick manufacturing sites were also derived from industry information about the extraction site locations, routes and the load state of the trucks during the return journey.

Data for the ceramic brick production process was collected from eight Portuguese manufacturers through questionnaires and audits, and also refers to the year 2008. The data provided by the manufacturers includes the brick composition, raw material and ancillary consumption, the amount of bricks produced (disaggregated by brick dimension), energy consumption, water consumption, data concerning transportation (type, distances, fuel), emissions to air and water, and waste. This data was measured directly in the factories and the annual results were obtained by the sum of all data from January to December for parameters such as energy, water, raw materials, ancillary materials and waste. Average data was considered when several measurements or data for each parameter was available, specifically for gaseous emissions. Moreover, data concerning lighting and other activities such as maintenance and cleaning was also collected.

Secondary data from the "Ecoinvent" database (Ecoinvent, 2009) was used for the remaining processes included in the boundaries like the production of electricity, fuels, steel, wood pallets, lubricating oil, as well as the emission factors for transports, mortar production and final disposal.

\subsubsection{Allocation procedure}

The brick factories under study are multifunctional systems because they produce bricks with dimensions other than $30 \times 20 \times 11 \mathrm{~cm}$. Therefore, it was necessary to allocate some of the inputs and outputs to the brick dimension under study. EN 15804 states that the allocation must respect the main purpose of the processes studied, including the relevant products and functions, and must be based on physical properties (e.g. mass, volume) when the difference in revenue from the co-products is low and on economic values for all other cases. Therefore, in this study the mass allocation procedure was adopted, which consists of splitting up the amounts of inputs and outputs proportionally to the brick mass 
in order to obtain the individual inputs and outputs for the $30 \times 20 \times 11 \mathrm{~cm}$ brick.

A sensitivity analysis was undertaken in order to evaluate the effects of using an economic allocation and to provide information to help in the elaboration of PCRs.

\subsubsection{Life cycle impact assessment}

The potential environmental impacts associated with the different kinds of resources and pollutant emissions were converted into impact categories using characterization factors (ISO, 2006c).

The selection of the impact categories rely on the following criteria, which reflect the critical issues on ceramic brick materials:

- inventory data availability and its relation with impact categories;

- environmental impact categories relevance identified by previous LCA studies on ceramic materials (Almeida et al., 2011; Bovea et al., 2007; Bribián et al., 2011; Center for Clean Products, 2009; Ibáñez-Forés et al., 2013; Koroneos and Dompros, 2007; Rouwette, 2010);

- impact categories defined in EN 15804 (CEN, 2012) for construction products and services.

The impact categories considered in this study were: abiotic resources depletion (AD), acidification $(A)$, eutrophication (E), global warming (GW), ozone layer depletion (OD), photochemical oxidation (PO) and respiratory inorganics (RI).

The calculations of these impact categories were performed using the CML database of characterization factors (Guinée et al., 2002), except for respiratory inorganics where the Impact 2000+ method (Pennington et al., 2005) was used as referred in a previous study that assessed ceramic cladding products (Center for Clean Products, 2009). The methods were running in the "SimaPro" software.

An energy indicator was also used - non-renewable fossil energy (NRE) based on the cumulative energy demand (CED) method (Huijbregts et al., 2005), which distinguishes between nonrenewable (fossil and nuclear) and renewable primary energy use (wind, solar, hydraulic, biomass and geothermal). In addition, a water indicator called water demand (WD) was used based on the water consumption. Moreover, an additional indicator regarding the emission of particles to air was tested.

\section{Results}

\subsection{Impact assessment results}

Table 2 shows the impact assessment results obtained for the different impact categories, considering the three fuel scenarios analysed (BIO - biomass, PC - petroleum coke and NG - natural gas). The results represent the average values obtained for each scenario and are expressed per functional unit ( $1 \mathrm{~m}^{2}$ of brick wall) and per declared unit of $1 \mathrm{~kg}$ of brick to facilitate comparison with other studies.

Fig. 3 presents the relative contribution of each stage in the life cycle of bricks to the considered impact categories and indicators, considering the three studied fuel scenarios.

The results show that for the different impact categories or indicators under study, the lowest impact was reached by the biomass or by the natural gas scenario. For abiotic depletion, global warming, ozone layer depletion and non-renewable fossil energy, the biomass achieved the lowest value, while for acidification, eutrophication, photochemical oxidation, respiratory inorganics and particles to air, the lowest value was reached in the natural gas scenario, although the values are in the same order of magnitude as those obtained for biomass. The highest impacts were obtained for the petroleum coke scenario, except for water demand. In the case of water demand, the values are quite similar as they depend mainly on the raw material moisture and the influence of the fuel is less relevant.

The product stage (includes A1, A2 and A3) is the most relevant for all categories except for global warming when using biomass (where the installation in the building (A5) represents 53\% of the total impact), respiratory inorganics when using natural gas (where C1-C4 represents $38 \%$ of the total impact), water demand for all fuel scenarios (where A5 represents $63-65 \%$ of the total impact), and particles for all fuel scenarios (where $\mathrm{C} 1-\mathrm{C} 4$ represents $49-75 \%$ of the total impact).

Module A3 is the most relevant for almost all the impact categories and indicators in this study, except for: eutrophication when using petroleum coke, where module A2 regarding the transportation to the manufacturer is the most significant factor; global warming and ozone depletion for the biomass scenario, where module A5 is the most relevant factor; respiratory inorganics when using natural gas, where the end of life modules (C1-C4) are more relevant; water demand for all fuel scenarios, where module A5 is the most relevant factor; and particles to air, where the end of life modules $(\mathrm{C} 1-\mathrm{C} 4)$ are the most significant factors.

The use phase in modules B1-B7 is not relevant for the environmental performance of this kind of ceramic brick as there is no consumption of materials or energy during this phase.

Regarding the abiotic depletion impact category, the highest value was obtained for the petroleum coke scenario, while the lowest was obtained for the biomass scenario, which reflects the type of fuel used. Module A3 is the most relevant module for abiotic depletion, representing 35\% for biomass and $71 \%$ for petroleum coke, followed by module A5 ( $27 \%$ and $13 \%$ for biomass and natural gas respectively) and module A1 for petroleum coke (10\%).

The acidification impact category is mainly associated with the emission of sulphur oxides $\left(\mathrm{SO}_{\mathrm{x}}\right)$ and nitrogen oxides $\left(\mathrm{NO}_{\mathrm{x}}\right)$ derived

Table 2

Environmental impact results from cradle to grave.

\begin{tabular}{|c|c|c|c|c|c|c|c|}
\hline \multirow[t]{2}{*}{ Impact category and indicators } & \multicolumn{3}{|c|}{ Declared unit: $1 \mathrm{~kg}$ of brick } & \multicolumn{3}{|c|}{ Functional unit: $1 \mathrm{~m}^{2}$ of brick } & \multirow[t]{2}{*}{ Unit } \\
\hline & Scenario BIO & Scenario PC & Scenario NG & Scenario BIO & Scenario PC & Scenario NG & \\
\hline Abiotic depletion (AD) & $6.25 \mathrm{E}-04$ & $1.96 \mathrm{E}-03$ & $1.27 \mathrm{E}-03$ & 4.47E-02 & $1.40 \mathrm{E}-01$ & $9.07 \mathrm{E}-02$ & $\mathrm{~kg} \mathrm{Sb} \mathrm{eq}$ \\
\hline Acidification $(\mathrm{A})$ & $6.84 \mathrm{E}-04$ & 3.62E-03 & $6.66 \mathrm{E}-04$ & 4.89E-02 & $2.59 \mathrm{E}-01$ & 4.77E-02 & $\mathrm{kg} \mathrm{SO}_{2} \mathrm{eq}$ \\
\hline Eutrophication (E) & $1.05 \mathrm{E}-04$ & $1.41 \mathrm{E}-04$ & 7.10E-05 & $7.48 \mathrm{E}-03$ & $1.01 \mathrm{E}-02$ & $5.08 \mathrm{E}-03$ & $\mathrm{~kg} \mathrm{PO}_{4}^{3-}$ eq \\
\hline Global warming (GW) & $1.32 \mathrm{E}-01$ & 3.03E-01 & 2.09E-01 & $9.47 \mathrm{E}+00$ & $2.17 \mathrm{E}+01$ & $1.50 \mathrm{E}+01$ & $\mathrm{~kg} \mathrm{CO}_{2}$ eq \\
\hline Ozone layer depletion (OD) & $1.01 \mathrm{E}-08$ & $3.86 \mathrm{E}-08$ & $2.01 \mathrm{E}-08$ & $7.20 \mathrm{E}-07$ & $2.76 \mathrm{E}-06$ & $1.44 \mathrm{E}-06$ & kg CFC-11 eq \\
\hline Photochemical oxidation (PO) & $6.11 \mathrm{E}-05$ & $1.52 \mathrm{E}-04$ & $4.05 \mathrm{E}-05$ & 4.37E-03 & $1.09 \mathrm{E}-02$ & $2.90 \mathrm{E}-03$ & $\mathrm{~kg} \mathrm{C}_{2} \mathrm{H}_{4}$ eq \\
\hline Non-renewable, fossil (NRE) & $1.26 \mathrm{E}+00$ & $4.29 \mathrm{E}+00$ & $2.60 \mathrm{E}+00$ & $9.03 \mathrm{E}+01$ & $3.07 \mathrm{E}+02$ & $1.86 \mathrm{E}+02$ & MJ eq \\
\hline Respiratory inorganics (RI) & $2.18 \mathrm{E}-04$ & 7.63E-04 & $1.38 \mathrm{E}-04$ & $1.56 \mathrm{E}-02$ & $5.46 \mathrm{E}-02$ & $9.85 \mathrm{E}-03$ & Kg PM2.5 eq \\
\hline Water demand (WD) & $9.31 \mathrm{E}-01$ & $9.13 \mathrm{E}-01$ & $9.16 \mathrm{E}-01$ & $6.66 \mathrm{E}+01$ & $6.53 \mathrm{E}+01$ & $6.56 \mathrm{E}+01$ & 1 \\
\hline Particles to air (PA) & 8.36E-04 & $8.38 \mathrm{E}-04$ & $5.46 \mathrm{E}-04$ & $5.98 \mathrm{E}-02$ & $6.00 \mathrm{E}-02$ & $3.91 \mathrm{E}-02$ & $\mathrm{~kg}$ \\
\hline
\end{tabular}




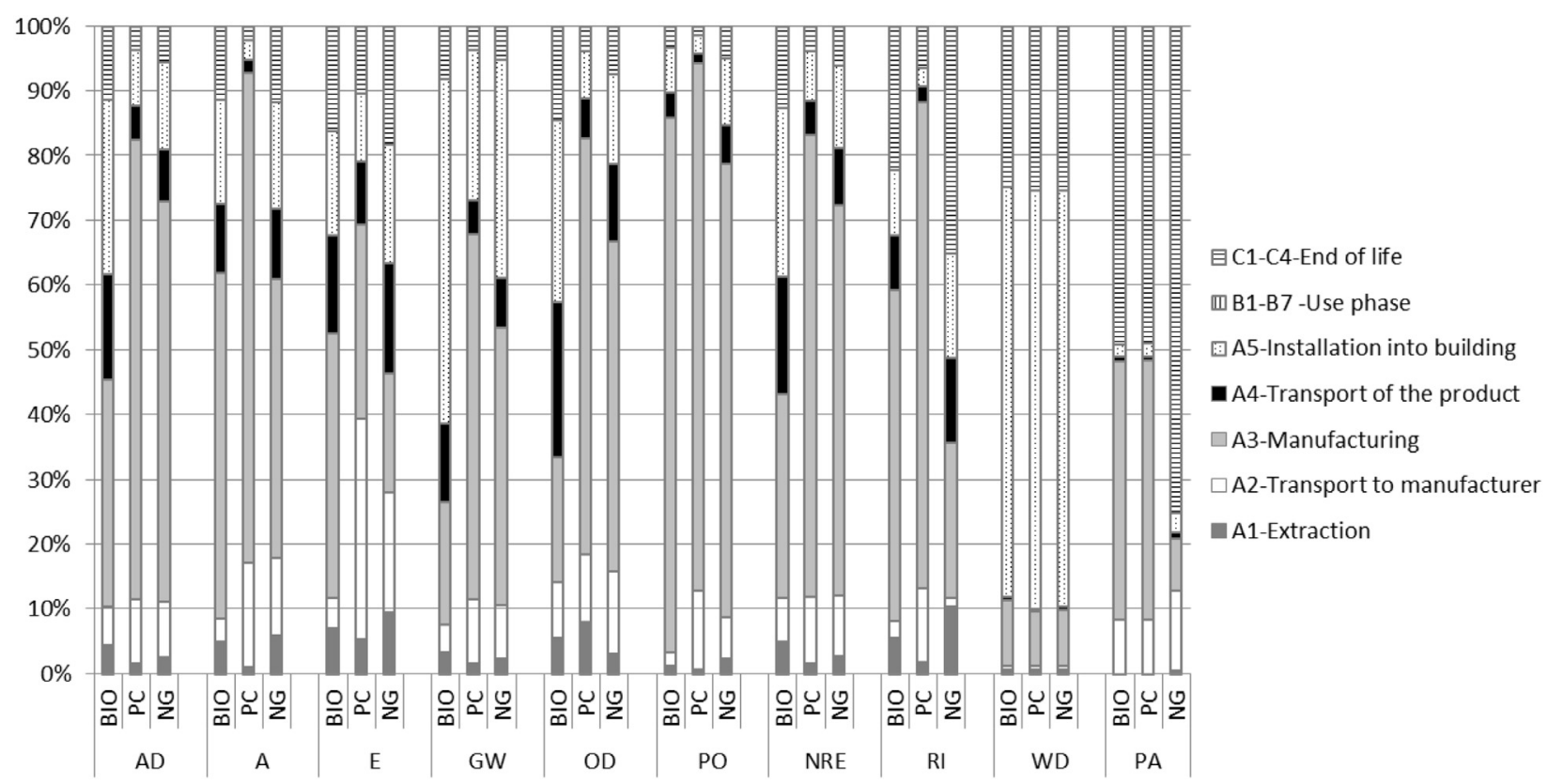

Fig. 3. Relative contribution of each module stage to different environmental impact categories and indicators, considering the studied scenarios.

from combustion processes. The petroleum coke has the highest content of sulphur, which could explain why the highest values were found in this impact category. On the other hand, natural gas has a low sulphur content, leading to lower values of acidification. The manufacturing stage (A3) represents between $43 \%$ and $76 \%$ of the total contribution to acidification, mainly due to the unit processes of drying and firing the ceramic material and to the production of electricity. Module A5 is the second most relevant, with a contribution of $16 \%$ in the biomass and natural gas scenarios, while for the petroleum coke scenario the second most relevant is module A2 (16\%).

The A3 module contributes from $18 \%$ to $41 \%$ to the total eutrophication, mainly due to $\mathrm{NO}_{\mathrm{x}}$ emitted from the fuel burned during the firing stage. The $\mathrm{NO}_{\mathrm{x}}$ emissions from the natural gas scenario in the manufacturing module were the lowest compared with the others fuels, which reflects the temperatures during the firing stage and also the low content of nitrogen in the fuel. Module A2 is the most relevant for the petroleum coke scenario, representing $34 \%$ of the eutrophication, which demonstrates the impact of the distance between the fuel producer and the brick factory.

For global warming, the manufacturing stage (A3) (especially the firing process due to having the highest consumption of fuel followed by the drying process) is the largest contributor to this category, representing $43 \%$ and $56 \%$ for the natural gas and petroleum coke scenarios respectively, except for the biomass scenario, where module A5 (53\%) represents the highest contribution. Biomass has the lowest global warming impact as biomass based $\mathrm{CO}_{2}$ emissions have been considered to be neutral as they are balanced by $\mathrm{CO}_{2}$ sequestration in forests, assuming that forests are managed in a sustainable way. For the petroleum coke and natural gas scenarios, module A5 contributes $23 \%$ and $34 \%$ respectively to this impact category. The less significant contributions to the global warming impact category come from the extraction (A1) and the end of life stage (C1-C4) modules.

In the ozone layer depletion impact category, the minimum value is reached by the biomass fuel scenario and the maximum value is reached by the petroleum coke scenario. The manufacturing stage (A3) plays a major role in terms of this category for the petroleum coke and natural gas scenarios, representing $64 \%$ and $51 \%$ respectively, followed by the A5 and A1 modules. When using biomass, module A5 represents $28 \%$ while module A3 represents $19 \%$. In terms of unit processes, electric energy production, fuel production, transport and mortar production are the major contributors.

In the photochemical oxidation category the manufacturing stage (A3) represents $70 \%-83 \%$ of the impact, with the drying and firing operations being the main contributors, which is mainly due to the burning of fuel used to produce the energy consumed in these operations, which emits $\mathrm{SO}_{\mathrm{x}}, \mathrm{CO}$ and volatile organic compounds (VOCs). $\mathrm{SO}_{\mathrm{x}}$ emissions also arise from the production of electrical energy, which is used in equipment during the product stage. The use of petroleum coke contributes to the highest values obtained in this category and the use of natural gas presents the lowest contribution which can be explained by the sulphur content in these fuels as previously mentioned.

Regarding non-renewable energy from fossil sources, the highest value was obtained for the petroleum coke scenario, while the lowest value was obtained for the biomass scenario, which can be explained by the type of fuel used and the fact that biomass is considered a renewable source. The manufacturing stage (A3) is the most relevant, representing $71 \%, 60 \%$ and $31 \%$ of the total impact respectively for the petroleum coke, natural gas and biomass scenarios, mainly due to the firing and drying unit processes.

Regarding respiratory inorganics, the lowest value was obtained for the natural gas scenario and the highest was obtained for the petroleum coke, due to the nature of these fuels. The manufacturing stage (A3) is the most relevant for petroleum coke (75\%) and biomass (51\%), while for natural gas the end of life stage (C1-C4) is the most relevant (35\%), followed by the manufacturing stage (A3).

Water consumption is related to the moisture content of clay, the cleaning of the facilities and the construction-installation module (consumption of water to prepare the mortar), and is not directly influenced by the type of fuel used. The installation stage 
Table 3

Cut-off criteria options (data for the functional unit: $1 \mathrm{~m}^{2}$ of brick).

\begin{tabular}{|c|c|c|c|c|c|}
\hline \multirow[t]{2}{*}{ Impact category: } & \multicolumn{4}{|l|}{ Options } & \multirow[t]{2}{*}{ Unit } \\
\hline & I (no cut-off) & II $(1 \%-$ EN 15804$)$ & III ( $0.5 \%$ of brick mass) & IV ( $1.0 \%$ of brick mass) & \\
\hline Abiotic depletion (AD) & $9.07 \mathrm{E}-02$ & $9.03 \mathrm{E}-02$ & $8.91 \mathrm{E}-02$ & $8.81 \mathrm{E}-02$ & kg Sb eq \\
\hline Acidification (A) & 4.77E-02 & 4.74E-02 & 4.59E-02 & $4.54 \mathrm{E}-02$ & $\mathrm{~kg} \mathrm{SO} \mathrm{eq}_{2}$ \\
\hline Eutrophication (E) & $5.08 \mathrm{E}-03$ & $5.04 \mathrm{E}-03$ & 4.97E-03 & $4.62 \mathrm{E}-03$ & $\mathrm{~kg} \mathrm{PO}_{4}^{3-}$ eq \\
\hline Global warming (GW) & $1.50 \mathrm{E}+01$ & $1.49 \mathrm{E}+01$ & $1.50 \mathrm{E}+01$ & $1.50 \mathrm{E}+01$ & $\mathrm{~kg} \mathrm{CO} 2 \mathrm{eq}$ \\
\hline Ozone layer depletion (OD) & $1.44 \mathrm{E}-06$ & $1.43 \mathrm{E}-06$ & $1.41 \mathrm{E}-06$ & $1.41 \mathrm{E}-06$ & kg CFC-11 eq \\
\hline Photochemical oxidation (PO) & $2.90 \mathrm{E}-03$ & $2.89 \mathrm{E}-03$ & $2.86 \mathrm{E}-03$ & $2.80 \mathrm{E}-03$ & $\mathrm{~kg} \mathrm{C}_{2} \mathrm{H}_{4}$ eq \\
\hline Non-renewable. fossil (NRE) & $1.86 \mathrm{E}+02$ & $1.85 \mathrm{E}+02$ & $1.82 \mathrm{E}+02$ & $1.80 \mathrm{E}+02$ & MJ eq \\
\hline Respiratory inorganics (RI) & $9.85 \mathrm{E}-03$ & $9.81 \mathrm{E}-03$ & $9.81 \mathrm{E}-03$ & $9.67 \mathrm{E}-03$ & kg PM2.5 eq \\
\hline \multicolumn{6}{|l|}{ Environmental indicators: } \\
\hline Water demand (WD) & $6.56 \mathrm{E}+01$ & $6.56 \mathrm{E}+01$ & $6.56 \mathrm{E}+01$ & $6.56 \mathrm{E}+01$ & $\mathrm{~m}^{3}$ \\
\hline Particles to air (PA) & $3.91 \mathrm{E}-02$ & $3.91 \mathrm{E}-02$ & $3.91 \mathrm{E}-02$ & $3.91 \mathrm{E}-02$ & $\mathrm{~kg}$ \\
\hline
\end{tabular}

(A5) is the most relevant stage, representing 63-64\%, followed by the end of life stage $(\mathrm{C} 1-\mathrm{C} 4)$ which represents $24-25 \%$ of the total impact.

Regarding particle emission to air, the lowest value was obtained for the natural gas scenario and the highest was obtained for the biomass and petroleum coke scenarios, as was expected due to the nature of these fuels. The end of life stage $(\mathrm{C} 1-\mathrm{C} 4)$ is the most relevant for this indicator, representing $49 \%$ for biomass and petroleum coke and $75 \%$ for natural gas. For the natural gas scenario, the most representative is $\mathrm{C} 1-\mathrm{C} 4$ followed by the transport stage (A2), which represents $12 \%$ of the total impact, and then the manufacturing stage (A3) with $8 \%$. For biomass and petroleum coke, the A3 module is also particularly relevant with a contribution of $40 \%$.

\subsection{Sensitivity analysis}

The three alternative cut-off criteria procedures for the "cradle to grave" approach (options II, III and IV) presented lower results than option I (no cut-off) as expected, but they were quite similar in almost all categories (Table 3 ).

The results obtained in option II using the cut-off criteria mentioned in the EN 15804 standard and represent more than 99\% of the results obtained for all impact categories without any cut-off criteria (option I). It should be noted that the application of this criterion assumes the inventory of all materials and energy for the unit processes. With this criterion, some industrial gases (oxygen, acetylene, propane) and metallic components (e.g. moulds) were excluded.

Options III and IV reflect the criteria that represent a percentage of the mass of the ceramic brick ready to be sold, respectively $0.5 \%$ and $1 \%$. With these criteria, the inventory phase can be speeded up as it is only necessary to look at materials consumed above these criteria, except if there are hazardous substances. The application of these two criteria provided similar inclusion of inputs and outputs with the exception of the euro pallet used in the packaging step, which is not included in scenario D.

In the case of option III, the impacts represent from $96.2 \%$ (for eutrophication) to $99.9 \%$ (for global warming) of the total impacts without any cut-off (option I).

For option IV, the impacts represent from $90.9 \%$ (for eutrophication) to $99.9 \%$ (for global warming) of the total impacts without any cut-off.

Regarding the particles to air and water demand indicators, the cut-off criteria do not affect this indicator as no significant process were affected.

Regarding the influence of allocation on the results, the adoption of different allocation procedures (mass and economic value) led to equal results because the final market price of several brick dimensions is proportional to their mass.

\section{Discussion}

\subsection{Impact results}

The results presented in the previous section show that the manufacturing stage (A3) of the brick is the most relevant stage for almost all impact categories and indicators studied and these impacts are mostly related to the significant energy consumption and corresponding emissions in A3, specifically in the firing stage.

Some LCA studies have been conducted on a number of ceramic products (e.g. Almeida et al., 2011; Bovea et al., 2007; Bribián et al., 2011; Center for Clean Products, 2009; Ibáñez-Forés et al., 2013; Koroneos and Dompros, 2007; Rouwette, 2010) and they all also report the high energy consumption in the ceramic manufacturing stage (production process), especially in the firing stage.

For ordinary bricks, Bribián et al. (2011) found a primary energy demand of $3.562 \mathrm{MJ}-\mathrm{eq} / \mathrm{kg}$ and a global warming impact of $0.271 \mathrm{~kg}$ $\mathrm{CO}_{2}$-eq/ $\mathrm{kg}$, which is quite consistent with the results obtained in this study for the natural gas and petroleum coke scenarios from a "cradle to grave" perspective. These authors also found a total water demand of $1.890 \mathrm{l} / \mathrm{kg}$ for all stages of the brick life cycle, which is higher than the figures obtained in this study. Although they did not discriminate the water demand distribution between stages, this higher value may reflect that the moisture content of the raw materials is lower and they need a higher quantity of water and/or there may be more water required in the installation phase.

Koroneos and Dompros (2007) developed an LCA study on a Greek brick $(17 \times 14 \times 28 \mathrm{~cm}$ with $5.945 \mathrm{~kg})$, in which petroleum coke was the main energy source (86.1\%) used in brick production. Although they used the EcoIndicator 95 impact assessment methodology, they determined that the global warming impact obtained was $0.221 \mathrm{~kg} \mathrm{CO}-\mathrm{eq} / \mathrm{kg}$ for the manufacturing, which is lower than the one obtained in our study for petroleum coke scenarios, and they did not include the end-of life stage or the consumption of mortar for the use phase. The acidification obtained was $2.229 \mathrm{~kg}$ $\mathrm{SO}_{2} \mathrm{eq} / \mathrm{t}$, which is quite similar to the value obtained for petroleum coke (A1-A3) and reflects the sulphur content in the fuel used. Finally, the result of $0.043 \mathrm{~kg} \mathrm{PO}_{4}^{3-} \mathrm{eq} / \mathrm{t}$ for eutrophication is lower than the one presented in Table 2 for petroleum coke, but is also coherent.

The results obtained in the LCA study of brick products for the Think Brick Australia (Rouwette, 2010), are also coherent with the ones presented in this study. They obtained a global warming of $2.4 \mathrm{~kg} \mathrm{CO}_{2} /$ ton of clay for the extraction phase, while in the present study the results obtained for the global warming category varied 
between $3.6 \mathrm{~kg} \mathrm{CO} / \mathrm{t}$ of clay and $4.4 \mathrm{~kg} \mathrm{CO} / \mathrm{t}$ of clay, which are higher but in the same order of magnitude. In the cradle to gate study for one standard brick (SBE) with natural gas as fuel, they obtained a cumulative energy demand of $9.5 \mathrm{MJ} / \mathrm{SBE}$ and a global warming of $2.4 \mathrm{~kg} \mathrm{CO} / \mathrm{SBE}$, which is equivalent to $3.1 \mathrm{MJ} / \mathrm{kg}$ of brick and $0.199 \mathrm{~kg} \mathrm{CO} / \mathrm{kg}$ of brick respectively. For the "cradle to grave" results a cumulative energy demand of $560 \mathrm{MJ} / \mathrm{m}^{2}$ and a global warming of $40 \mathrm{~kg} \mathrm{CO} / \mathrm{m}^{2}$ was obtained for the Australian brick, which is equivalent to $4.2 \mathrm{MJ} / \mathrm{kg}$ of brick and $0.301 \mathrm{~kg} \mathrm{CO}_{2} / \mathrm{kg}$ of brick. These results are higher than the ones obtained for Portuguese brick factories operating with natural gas. The Australian study also pointed out that the GHG emissions during the entire life cycle of a brick wall are dominated by the cradle to gate brick manufacturing process (68\%). They also argue that the demolition of the wall contributes less than $1 \%$ to the total GHG emissions.

\subsection{Cut-off rules}

The scenarios applied in this study gave slightly different results for the impact categories and indicators as they rely on different cut-off criteria procedures.

The cut-off criteria adopted in EN 15804 proved to be reasonably adequate as it represents more than $99.6 \%$ of the total impacts; however, it still requires previous work in terms of the collection of all inventory data.

The cut-off criteria adopted when using $0.5 \%$ of the mass of the ceramic brick ready to be sold proved to be adequate because it allows the quantification of $97.6-99.6 \%$ of the impacts with relatively small effort in terms of data collection.

\subsection{Allocation rules}

In the present study, it was concluded that both mass and economic allocation procedures give equal results for the brick under study, because the factors that influence the brick price are related to the production cost (e.g. raw materials, ancillaries and energy) and, therefore, the price by brick dimension is proportional to the mass.

\section{Conclusions}

The main conclusions of the present study regarding the environmental performance of the ceramic brick analysed and used as a construction material in a single layer brick wall are:

- the product stage (includes A1, A2 and A3) is the most relevant for all categories except for global warming when using biomass (where the installation in the building (A5) represents $53 \%$ of the total impact), respiratory inorganics when using natural gas, water demand for all fuel scenarios (where A5 represents $63-65 \%$ of the total impact), and particles to air for all fuel scenarios (where $\mathrm{C} 1-\mathrm{C} 4$ represents $49-75 \%$ of the total impact).

- the highest impact for almost all the categories and indicators studied occurs during the brick manufacturing stage (module A3), except for respiratory inorganics when using natural gas (C1-C4 are the most relevant), for water demand (A5 is the most relevant), particles to air ( $\mathrm{C} 1-\mathrm{C} 4$ are the most relevant), eutrophication when using petroleum coke as fuel (A2 is the most relevant), and global warming and ozone depletion for the biomass scenario, where installation (module A5) is the most relevant;

- the highest potential for improving the environmental performance of the studied ceramic materials is associated with energy consumption during the manufacturing stage (A3), specifically the firing unit of the ceramic material, since it requires a greater use of energy (compared to other processes) and hence a significant emission of pollutants into the atmosphere. Thus, the firing process has greater potential in terms of reducing the environmental impacts for the impact categories usually selected in EPDs. Measures such as reducing the firing temperature of the ceramic brick, adding fluxes or other additives are possibilities for reducing the environmental impact;

- the use of different fuels can have a significant effect in certain impact categories like global warming, eutrophication, photochemical oxidation and non-renewable fossil energy demand for a cradle to grave LCA;

- the brick factories that operate with petroleum coke have higher impacts than those operating with natural gas or biomass, except for water demand, which is not affected by the type of fuel;

- although the use of natural gas is considered a BAT according to the Reference Document on Best Available Techniques in the Ceramic Manufacturing Industry (BREF) (EC, 2008), in some impact categories such as global warming and abiotic depletion the use of biomass leads to a better performance. However, the consideration of natural gas as a BAT is understandable because one of the main problems when burning solid fuels like biomass is particle emissions;

- the data obtained in this study for the brick production covers the most relevant fuels used in the production of bricks in Portugal and, therefore, can constitute a background database or indicative reference values for the development of EDPs.

In addition, the following conclusions related to the elaboration of a PCR for ceramic bricks can also be drawn:

- the cut-off criteria of $0.5 \%$ in mass of the ceramic brick ready to be sold proved to be adequate for adoption, with a significant reduction in the effort required for data collection;

- the allocation rule based on mass (physical property) proved to be adequate for this kind of product;

- the use of specific data is relevant during the manufacturing stage due to the use of different kinds of fuels as well as water consumption (geographic location);

- the impact category of respiratory inorganics and the emission of total particles to air should be considered as additional indicators, being especially important when solid fuels are used. It should be noted that EN 15804 for construction products does not require this impact category nor this indicator.

\section{Acknowledgements}

Thanks are due to the FCT (Science and Technology Foundation - Portugal) for the scholarship granted to Ana Cláudia Dias (SFRH/ BPD/75788/2011) and the Technological Centre for Ceramics and Glass Industry (CTCV Portugal) for the financial support for Marisa Almeida's doctoral studies.

\section{References}

Almeida, M., Dias, A.C., Arroja, L., 2011. Environmental product declaration in Portuguese ceramic tile. In: Fernandes, et al. (Eds.), Proceedings da SIM $2011-$ International Conference on Sustainable Intelligent Manufacturing. Leiria, Portugal.

Bovea, M.D., Saura, U., Ferrero, J.L., Giner, J., 2007. Cradle to gate study of red clay for use in the ceramic industry. Int. J. Life Cycle Assess. 12 (6), 439-447.

Bribián, I.Z., Capilla, A.V., Usón, A.A., 2011. Life cycle assessment of building materials: comparative analysis of energy and environmental impacts and evaluation of the eco-efficiency improvement potential. Build. Environ. 46, 1133-1140.

CEN, 2011. NP EN 771 Part 1 - Specification for Masonry Units - Part 1: Clay Masonry Units. European Committee for Standardization, Brussels.

CEN, 2012. EN 15804: Sustainability of Construction Works - Environmental Product Declarations - Core Rules for the Product Category of Construction Products. European Committee for Standardization, Brussels. 
Center for Clean Products, 2009. Life-cycle Assessment of Cladding Products: a Comparison of Aluminum, Brick, Granite, Limestone, and Precast Concrete. University of Tennessee, Knoxville.

EC, 2001. Green Paper on Integrated Product Policy. COM 68 Final. European Commission, Brussels.

EC, 2008. BREF: Reference Document on Best Available Techniques in the Ceramic Manufacturing Industry. European Commission, Institute for Prospective Technological Studies, Seville.

EC, 2011a. EU regulation 305/2011 of the European Parliament and of the council of 9 March 2011 on harmonised conditions for the marketing of construction products and repealing council directive 89/106/EEC. Off. J. Eur. Union L88/5. European commission, Brussels.

EC, 2011b. Roadmap to a Resource Efficient Europe. COM (2011) 57. European Commission, Brussels.

Eco plataform, 2014. Objectives and Added Value of the ECO Platform. Available at: http://www.eco-platform.org/home.html (accessed 05.05.14.).

Ecoinvent, 2009. The Life Cycle Inventory. Data V. Switzerland, Swiss Centre for Life Cycle Inventories, Swiss.

Guinée, J.B., Gorrée, M., Heijungs, R., Huppes, G., Kleijn, R., Koning, A., Oers, L. Wegener, S.A., Sub, S., Udo de Haes, H.A., Bruijn, H., Duin, R., Huijbregts, M.A.J, 2002. Handbook on Life Cycle Assessment. Operational guide to the ISO standards. I: LCA in perspective. IIa: Guide. IIb: Operational annex. III: Scientific background. Kluwer Academic Publishers, Dordrecht, ISBN 1-4020-0228-9.

Huijbregts, M.A.J., Rombouts, L.J.A., Hellweg, S., Frischknecht, R., Hendriks, A.J., van de Meent, D., Ragas, A.M.J., Reijnders, L., Struijs, J., 2005. Is cumulative fossil energy demand a useful indicator for the environmental performance of products? Environ. Sci. Technol. 40 (3), 641-648.

Hunsager, E., Bach, M., Breuer, L., 2014. An institutional analysis of EPD programs and a global PCR registry. Int. J. Life Cycle Assess. 19, 786-795.

Ibáñez-Forés, V., Bovea, M.D., Azapagic, A., 2013. Assessing the sustainability of Bes Available Techniques (BAT): methodology and application in the ceramic tiles industry. J. Clean. Prod. 51, 162-176.

Ingwersen, W., Stevenson, M., 2011. Can we compare the environmental performance of this product to that one? An update on the development of product category rules and future challenges toward alignment. J. Clean. Prod. 24 $102-108$.

Ingwersen, W. Subramanian, V. (Eds.), 2013. Guidance for Product Category Rules Development. Available at: http://www.pcrguidance.org/ (accessed 28.08.13.).

ISO, 1999a. ISO 14021: Environmental Labels and Declarations - Self-declared Environmental Claims (Type II Environmental Labelling). International Organization for Standardization, Geneva.

ISO, 1999b. ISO 14024: Environmental Labels and Declarations - Type I Environmental Labelling - Principles and Procedures. International Organization for Standardization, Geneva.
ISO, 2006a. ISO 14020: Environmental Labels and Declarations - General Principles. International Organization for Standardization, Geneva.

ISO, 2006b. ISO 14025: Environmental Labels and Declarations - Type III Environmental Declarations - Principles and Procedures. International Organization for Standardization, Geneva.

ISO 2006c. ISO 14040: Environmental Management - Life Cycle Assessment Principles and Frameworks. International Organization for Standardization, Geneva.

ISO, 2006d. ISO 14044: Environmental Management - Life Cycle Assessment Requirements and Guidelines. International Organization for Standardization, Geneva.

ISO, 2007. ISO 21930: Sustainability in Building Construction - Environmental Declaration of Building Products. International Organization for Standardization, Geneva.

ISO, 2008. ISO Guide 64: Guide for Addressing Environmental Issues in Product Standards. International Organization for Standardization, Geneva.

Koroneos, C., Dompros, A., 2007. Environmental assessment of brick production in Greece. Build. Environ. 42, 2114-2123.

Misiga, P., 2012. Sustainability of construction products in the context of the emerging European resource efficiency policy. In: Stakeholder Workshop Measuring Sustainability in Construction: Building Coherent Tools with Product Category Rules (PCRs). TBE, Brussels.

Modahl, I.S., Askham, C., Lyng, K., Skjerve-Nielssen, C., Nereng, G., 2013. Comparison of two versions of an EPD, using generic and specific data for the foreground system, and some methodological implications. Int.J Life Cycle Assess 18, $241-251$.

Pennington, D.W., Margni, M., Amman, C., Jolliet, O., 2005. Multimedia fate and human intake modeling: spatial versus non-spatial insights for chemical emissions in Western Europe. Environ. Sci. Technol. 39 (4), 1119-1128.

Ronning, A., Lyng, K., 2011. State of the art study - how is environmental performance measured for buildings/constructions?. In: Life Cycle Management Conference - LCM 2011, first ed., vol. 1. Springer, Berlin, pp. 141-154.

Rouwette, R., 2010. LCA of Brick Products: Life Cycle Assessment Report - Final Report after Critical Review. Think Brick Australia J/N 107884, Australia.

Secil, 2005. Argamassa de alvenaria, argamassa de assentamento. Available at: http://www.secilargamassas.pt/ (accessed 28.04.12.).

Subramanian, V., Ingwersen, W., Hensler, C., Collie, H., 2012. Comparing product category rules from different programs: learned outcomes towards global alignment. Int. J. Life Cycle Assess. 17, 892-903.

Zackrisson, M., Rocha, C., Christiansen, K., Jarnehammar, A., 2008. Stepwise environmental product declarations: ten SME case studies. J. Clean. Prod. 16, $1872-1886$. 